\title{
GAMBARAN FAKTOR YANG \\ BERHUBUNGAN DENGAN PERILAKU DETEKSI DINI KANKER SERVIKS DI KECAMATAN MANONJAYA KABUPATEN TASIKMALAYA TAHUN 2015 \\ OLEH : \\ HARIYANI S, S.KM,M.KM
}

\section{A. ABSTRAK}

Penelitian WHO menyingkapkan kurangnya tindakan skrining penyakit kanker di Indonesia.Khususnya untuk skrining kanker serviks yaitu sitologi serviks dan ulasan asam asetat, secara umum belum tersedia di pusat kesehatan primer pada tahun 2014. Ini ikut berpengaruh pada jumlah kematian kanker serviks di Indonesia yang tergolong tinggi karena sebagian besar disebabkan oleh keterlambatan dalam diagnosis. Tujuan dari penelitian ini adalah mengetahui gambaran faktor yang mempengaruhi perilaku deteksi dini kanker servik di wilayah Kecamatan Manonjaya Kabupaten Tasikmalaya tahun 2015

Jenis penelitian yang digunakan adalah kuantitatif dengan metode deskriptif. Populasi dalam penelitian ini adalah seluruh wanita usia subur di wilayah Kecamatan Manonjaya periode September 2015 sebanyak 412 orang. Tehnik pengambilan sampel dalam penelitian ini adalah simpel random sampling sebanyak 202 responden. Variabel dalam penelitian ini adalah pengetahuan, dukungan suami dan perilaku deteksi dini kanker serviks. Instrumen dalam penelitian ini menggunakan kuesioner 10 pertanyaan untuk pengetahuan, 1 pertanyaan untuk dukungan dan 1 pertanyaan untuk perilaku. Analisis data dalam penelitian ini adalah analisis univariat.

Hasil penelitian ini didapatkan mayoritas pengetahuan responden tentang deteksi dini kanker serviks adalah kurang yaitu 108 orang (53,46\%), sedngkan tingkat pendidikan responden mayoritas adalah tingkat dasar yaitu 112 orang atau $55.4 \%$, Mayoritas responden tidak mendapatkan dukungan suami untuk melakukan deteksi dini kanker serviks yaitu 134 orang (66,3\%) serta Responden yang melakukan deteksi dini kanker serviks adalah 19 orang (9,4\%).

Saran bagi masyarakat adalah dapat meningkatkan pengetahuan melalui pencarian informasi di berbagai media massa atau mengikuti penyuluhan kesehatan tentang pentingnya deteksi dini kanker serviks. Serta bagi tenaga kesehatan diharapkan petugas kesehatan berperan aktif dalam mensosialisasikan pentingnya deteksi dini kanker serviks melalui penyuluhan maupun konseling kesehatan.

Kata kunci : Pengetahuan, pendidikan, dukungan suami dan perilaku deteksi dini kanker serviks 


\section{B. PENDAhuluan}

Kanker serviks merupakan kanker yang terjadi pada serviks atau leher rahim, suatu daerah pada organ reproduksi wanita yang merupakan pintu masuk ke arah rahim, letaknya antara rahim (uterus) dan liang senggama atau vagina.

Pada tahun 2014, WHO menyatakan terdapat lebih dari 92 ribu kasus kematian pada penduduk wanita akibat penyakit kanker. Sebesar 10,3 persennya merupakan jumlah kematian akibat kanker serviks. Sedangkan jumlah kasus baru kanker serviks berjumlahhampir 21 ribu.

Sejak tahun 2000 hingga tahun 2012, semakin muda usia wanita yang terserang kanker serviks, yaitu kisaran usia 21-22 tahun di tahun 2000 dan mencapai usia di bawah 20 tahun pada tahun 2012. Penelitian WHO menyingkapkan kurangnya tindakan skrining penyakit kanker di Indonesia.Khususnya untuk skrining kanker serviks yaitu sitologi serviks dan ulasan asam asetat, secara umum belum tersedia di pusat kesehatan primer pada tahun 2014. Ini ikut berpengaruh pada jumlah kematian kanker serviks di Indonesia yang tergolong tinggi karena sebagian besar disebabkan oleh keterlambatan dalam diagnosis. Biasanya, kanker sudah menyebar ke organ lain di dalam tubuh ketika seseorang memeriksakan kondisinya. Inilah penyebab pengobatan yang dilakukan menjadi semakin sulit.

Menurut Wiknjosastro (2010) kanker serviks dapat disembuhkan jika dideteksi dan ditanggulangi sejak dini, malahan sebenarnya kanker serviks ini dapat dicegah. Menurut ahli Obgyn dari Newyork University Medical Center, Goldstein, kuncinya adalah deteksi dini. Di negara berkembang termasuk Indonesia adalah dengan menggunakan metode IVA, karena teniknya mudah/sederhana, biaya rendah/murah dan tingkat sensitifitasnya tinggi, cepat dan akurat untuk menemukan kelainan pada tahap kelainan sel (displasia), untuk itu dianjurkan Tes IVA bagi semua perempuan sudah melakaukan hubungan seksual (Depkes, 2007).

Pentingnya deteksi dini dilakukan untuk mengurangi prevalensi jumlah penderita dan untuk mencegah terjadinya kondisi kanker pada stadium lanjut. Metode untuk melakukan deteksi dini kanker serviks adalah dengan pap smear, selain metode ini ada metode lain yang dapat digunakan yaitu dengan metode IVA test, Thin Prep, dan kolposkopi.

Faktor penyebab yang lain dari kanker serviks adalah hubungan seks terlalu dini, terlambat menikah, dan berganti -ganti pasangan. ( Smart, 2010).Salah satu faktor penentu yang dapat mempengaruhi perilaku kesehatan adalah faktor predisposisi yang terwujud dalam pengetahuan, sikap, kepercayaan, keyakinan, informasi dan minat (Notoadmojo, 2003).

Pengetahuan sangat berpengaruh terhadap perilaku seseorang. Sebagian besar penderita kanker datang sudah dalam stadium lanjut sehingga prosesnya sulit atau tak mungkin lagi disembuhkan. Hal ini menunjukkan bahwa pengetahuan masyarakat tentang kanker serviks masih tergolong rendah, sehingga kesadaran masyarakat untuk skrining kanker serviks juga rendah.

Tujuan dari penelitian ini adalah mengetahui gambaran faktor yang mempengaruhi perilaku deteksi dini kanker servik di wilayah Kecamatan Manonjaya Kabupaten Tasikmalaya tahun 2015

\section{METODOLOGI PENELITI}

1. Jenis penelitian

Jenis penelitian yang digunakan adalah kuantitatif dengan metode deskriptif.

2. Populasi dan sampel

Populasi dalam penelitian ini adalah seluruh wanita usia subur di wilayah Kecamatan Manonjaya periode September 2015 sebanyak 412 orang. Tehnik pengambilan 
sampel dalam penelitian ini adalah simpel random sampling sebanyak 202 responden.

3. Waktu penelitian adalah bulan Oktober desember 2015

Tempat penelitian : Wilayah kerja Puskesmas Ciawi

4. Variabel

Variabel dalam penelitian ini adalah pengetahuan, dukungan suami dan perilaku deteksi dini kanker serviks.

5. Instrumen penelitian

Instrumen dalam penelitian ini menggunakan kuesioner 10 pertanyaan untuk pengetahuan, 1 pertanyaan untuk dukungan dan 1 pertanyaan untuk perilaku .

6. Pengolahan data

Pengolahan data penelitian dilakukan dengan cara :

\section{a. Editing}

Tahapan ini dilakukan dengan cara mengecek kelengkapan kebutuhan data penelitian.

b. Coding

Pemberian kode untuk setiap pilihan jawaban seperti :

1. Untuk variabel 1 untuk pengetahuan Baik, 2 untuk Cukup dan 3 untuk kurang.

2. Untuk variabel pendidikan 1 untuk pendidikan dasar, 2 untuk pendidikan menengah serta 3 untuk pendidikan tinggi.

3. Untuk variabel dukungan suami, 1 untuk mendukung dan 2 untuk tidak mendukung.

4. Untuk variabel perilaku deteksi dini, 1 untuk ya melakukan dan 2 untuk tidak melakukan.

5. Entry data

Proses memasukan data ke program komputerisasi untuk disajikan dalam bentuk tabel dan dianalisis secara narasi
7. Analisis data

Analisis data dalam penelitian ini adalah analisis univariat. Analisis ini menghasilkan distribusi frekuensi untuk menggambarkan tiap-tiap variabel yang akan diteliti.

D. HASIL PENELITIAN

1. Gambaran pengetahuan tentang kanker serviks pada Wanita usia subur di Kecamatan Manonjaya Kabupaten Tasikmalaya tahun 2015

Tabel 4.1

Distribusi Frekwensi pengetahuan responden tentang deteksi dini kanker serviks di Kecamatan Manonjaya kabupaten Tasikmalaya Tahun 2015

\begin{tabular}{|c|l|c|c|}
\hline No & Pengetahuan & F & \% \\
\hline 1 & Baik & 18 & 8.91 \\
\hline 2 & Cukup & 76 & 37.6 \\
\hline 3 & Kurang & 108 & 53.46 \\
\hline & & $\mathbf{2 0 2}$ & $\mathbf{1 0 0}$ \\
\hline
\end{tabular}

Berdasarkan tabel 4.1 didapatkan bahwa mayoritas pengetahuan responden tentang deteksi dini kanker serviks adalah kurang yaitu 108 orang $(53,46 \%)$

2. Gambaran tingkat pendidikan responden

Tabel 4.2

Distribusi Frekwensi tingkat pendidikan Wanita Usia Subur di Kecamatan Manonjaya kabupaten Tasikmalaya Tahun 2015

\begin{tabular}{|c|c|c|c|}
\hline No & Pendidikan & $\mathbf{F}$ & $\%$ \\
\hline 1 & Dasar & 112 & 55.4 \\
\hline 2 & Menengah & 80 & 39.6 \\
\hline 3 & Tinggi & 10 & 4.9 \\
\hline & Jumlah & 202 & 100 \\
\hline
\end{tabular}

Berdasarkan tabel 4.2 didapatkan bahwa mayoritas tingkat pendidikan responden mayoritas adalah tingkat dasar yaitu 112 orang atau $55.4 \%$ 
3. Gambaran dukungan suami terhadap responden untuk melakukan deteksi dini kanker serviks.

Tabel 4.3

Distribusi Frekwensi dukungan suami terhadap responden untuk melakukan deteksi dini kanker serviks di Kecamatan Manonjaya kabupaten Tasikmalaya Tahun 2015

\begin{tabular}{|c|c|c|c|}
\hline No & Dukungan & $\mathbf{F}$ & $\%$ \\
\hline 1 & Mendukung & 68 & 33.66 \\
\hline 2 & $\begin{array}{l}\text { Tidak } \\
\text { mendukung }\end{array}$ & 134 & 66.3 \\
\hline & Jumlah & 202 & 100 \\
\hline
\end{tabular}

Berdasarkan tabel 4.3 didapatkan bahwa responden tidak mendapatkan dukungan suami untuk melakukan deteksi dini kanker serviks yaitu 134 orang $(66,3 \%)$

4. Gambaran perilaku deteksi dini kanker serviks.

\section{Tabel 4.4}

Distribusi Frekwensi dukungan perilaku deteksi dini kanker serviks pada WUS di Kecamatan Manonjaya kabupaten Tasikmalaya Tahun 2015

\begin{tabular}{|c|c|c|c|}
\hline No & Dukungan & $\mathbf{F}$ & $\%$ \\
\hline 1 & $\mathrm{Ya}$ & 19 & 9.4 \\
\hline 2 & Tidak & 183 & 90.5 \\
\hline & Jumlah & 202 & 100 \\
\hline
\end{tabular}

Berdasarkan tabel 4.4 didapatkan bahwa responden yang melakukan deteksi dini kanker serviks adalah 19 orang $(9,4 \%)$

\section{E. PEMBAHASAN}

1. Pengetahuan dan perilaku deteksi dini kanker serviks

Berdasarkan hasil penelitian didapatkan bahwa mayoritas pengetahuan responden tentang deteksi dini kanker serviks adalah kurang yaitu 108 orang $(53,46 \%)$.

Rendahnya pengetahuan responden tentang perilaku deteksi dini kanker serviks memberikan kontribusi dalam terbentuknya perilaku deteksi dini kanker serviks. Hal ini sesuai dengan teori LW Green salah ssatu faktor yang mempengaruhi perilaku adalah pengetahuan dimana menurut Notoatmodjo (2003) Pengetahuan merupakan hasil dari tahu, dan ini terjadi setelah orang melakukan penginderaan terhadap suatu objek tertentu. Penginderaan terjadi melalui panca indera manusia, yakni indera penglihatan, pendengaran, penciuman, rasa, dan raba. Sebagian besar pengetahuan manusia diperoleh melalui mata dan telinga. Dari sumber pengetahuan tersebut dapat mempengaruhi dan digunakan seseorang sebagai dasar untuk berperilaku khususnya perilaku mereka untuk melakukan hal baru, misalnya: deteksi dini kanker serviks.

Pengetahuan pasangan usia subur tentang deteksi dini kanker serviks dapat diperoleh dari berbagai macam sumber informasi seperti media massa, media elektronik, buku, petugas kesehatan, poster, kerabat dekat dan sebagainya.

Hal ini sesuai dengan penelitian Nungky Marsela di surakarta tahun 2013 didapatkan mayoritas wanita usia subur memiliki pengetahuan kurang tentang deteksi dini kanker serviks.

Dibutuhkan upaya yang maksimal untuk meningkatkan pengetahuan masyarakat tentang pentingnya pemeriksaan dini ca cerviks.

\section{Tingkat Pendidikan dan perilaku deteksi dini kanker serviks}

Berdasarkan hasil penelitian didapatkan bahwa mayoritas tingkat pendidikan responden mayoritas adalah tingkat dasar yaitu 112 orang atau $55.4 \%$

Responden dengan tingkat pendidikan rendah disinyalir turut mempengaruhi terhadap perilaku deteksi dini kanker serviks. Hal ini didukung oleh Notoatmodjo (2005),yang menyatakan bahwa pendidikan adalah salah satu faktor yang sangat 
mempengaruhi perilaku masyarakat, apabila pendidikan masyarakat tinggi maka mereka akan mengerti dan memahami akan pentingnya melakukan pemeriksaan IVA dan sebaliknya apabila pendidikan masyarakat rendah, maka mereka akan mengabaikan dan tidak mengerti akan pentingnya pelayanan kesehatan khususnya pada pemeriksaan IVA.

Makin tinggi tingkat pendidikan seseorang, maka makin mudah menerima informasi sehingga makin banyak pula pengetahuan yang dimiliki. Sebaliknya pendidikan yang kurang akan menghambat perkembangan sikap seseorang terhadap nilai-nilai baru yang diperkenalkan.

\section{Dukungan suami dan perilaku deteksi dini kanker serviks}

Berdasarkan tabel 4.3 didapatkan bahwa responden tidak mendapatkan dukungan suami untuk melakukan deteksi dini kanker serviks yaitu 134 orang $(66,3 \%)$. Salah satu factor yang turut mempengaruhi wanita usia subur dalam mendeteksi dini kanker serviks adalah dukungan suami.

Di Indonesia dengan mayoritas masyarakat menganut patrialistiks atau garis suami dimana semua perilaku atau pengambilan keputusan untuk menghasilkan perilaku pada seorang istri harus mendapatkan persetujuan dari suami. Begitu pula dengan perilaku deteksi dini kanker serviks perlu mendapatka ijin dan dukungan suami. Hal ini sesuai dengan Susanti (2002) Friedman (1961) mengatakan bahwa sebelum seorang individu mencari pelayanan kesehatan yang profesional, ia biasanya mencari nasihat dari keluarga dan teman-temannya.peran keluarga sebagai kelompok kecil yang terdiri dari individu - individu yang mempunyai hubungan satu sama lain, saling tergantung merupakan sebuah lingkungan sosial, dimana secara efektif keluarga memberikan rasa aman, secara ekonomi keluarga berfungsi untuk mengadakan sumber-sumber ekonomi yang memadai untuk menunjang proses perawatan, secara sosial keluarga menumbuhkan rasa percaya diri, memberi umpan balik, membantu memecahkan masalah, sehingga tampak bahwa peran dari keluara sangat penting untuk setiap aspek kesehatan.

Asumsi peneliti dibutuhan upaya sosialisasi pentingnya deteksi dini kanker serviks tidak hanya pada sasaran (WUS) akan tetapi melibatkan orang orang terdekat dengan sasaran sebagai factor yang memberikan kekuatan dalam pengambilan keputusan.

\section{Perilaku deteksi dini kanker serviks}

Berdasarkan tabel 4.4 didapatkan bahwa responden yang melakukan deteksi dini kanker serviks adalah 19 orang $(9,4 \%)$. Rendahnya perilaku deteksi dini kanker serviks di wilayah ini.

Perilaku adalah bentuk respon atau reaksi terhadap stimulus atau rangsangan dari luar orgabisme (orang ), namun dalam memberikan respon tergantung pada karakteristik atau faktorfaktor lain dari orang yang bersangkutan. Hal ini berarti meskipun stimulusnya sama bagi beberapa orang, namun reson tiap orang berbeda. ( Notoatmodjo, 2007).

Perilaku deteksi dini kanker serviks sendiri merupakan suatu bentuk respon pemeriksaan yang berguna sebagai pemeriksaan penyaring (skrening) dan adanya pelacak perubahan sel ke arah keganasan secara dini sehingga kelainan pra kanker dapat terdeteksi secara dini. Deteksi dini kanker serviks dilakukan dengan pemeriksaan pap-smear. Bagi wanita berusia lebih dari 25 tahun yang telah menikah atau sudah melakukan senggama, dianjurkan untuk papsmearsekali setahun secara teratur. (Dalimartha, 2004).Bentuk perilaku 
deteksi dini Kanker Serviks seseorang dilihat dari bentuk respons terhadap stimulus, maka perilaku dapat dibedakan menjadi dua: Perilaku tertutup (Covert Behaviour) dan perilaku terbuka (Overt Behaviour).

Pada perilaku deteksi dini kanker serviks respons terhadap stimulus tersebut sudah jelas dalam bentuk tindakan atau praktik (practice), yang dengan mudah dapat diamati atau dilihat oleh orang lain. Oleh sebab itu disebut overt behaviour, tindakan nyata atau praktik (practice) misalnya: seorang ibu memeriksakan keadaan serviksnya atau dengan mewujudkannya dalam bentuk perilaku deteksi dini kanker serviks. Respons seseorang tertutup (cover behaviourt). Respons atau reaksi terhadap stimulus ini masih terbatas pada perhatian, persepsi, sikap yang terjadi pada orang yang menerima stimulus tersebut, dan belum dapat diamati secara jelas oleh orang lain misalnya: seorang ibu rumah tangga tahu pentingnya deteksi dini kanker serviks. (Notoatmojo, 2007)

\section{F. SIMPULAN DAN SARAN}
1. Simpulan
a. Mayoritas pengetahuan responden tentang deteksi dini kanker serviks adalah kurang yaitu 108 orang $(53,46 \%)$

b. Mayoritas tingkat pendidikan responden mayoritas adalah tingkat dasar yaitu 112 orang atau $55.4 \%$

c. Mayoritas responden tidak mendapatkan dukungan suami untuk melakukan deteksi dini kanker serviks yaitu 134 orang $(66,3 \%)$

d. Responden yang melakukan deteksi dini kanker serviks adalah 19 orang $(9,4 \%)$

e. Responden yang melakukan deteksi dini kanker serviks adalah 19 orang $(9,4 \%)$
2. Saran

a. Masyarakat

Diharapkan masyarakat meningkatkan pengetahuan melalui pencarian informasi di berbagai media massa atau mengikuti penyuluhan kesehatan tentang pentingnya deteksi dini kanker serviks.

b. Tenaga kesehatan

Diharapkan petugas kesehatan berperan aktif dalam mensosialisasikan pentingnya deteksi dini kanker serviks melalui penyuluhan maupun konseling kesehatan.

\section{G. DAFTAR PUSTAKA}

Indrawati,Maya.,2009. Bahaya

Kanker Bagi Wanita dan Pria, AV Publisher, Cetakan pertama, Jakarta.

Kumalasari, Intan., Andhyantoro, Iwan.,2012. Kesehatan Reproduksi, Salemba Medika, Jakarta.

Mansur, Herawati.,2009. Psikologi Ibu dan Anak Untuk Kebidanan, Salemba Medika, Jakarta.

Mubarak, Wahit Iqbal.,2011.

Promosi Kesehatan Untuk Kebidanan, Salemba Medika,Jakarta.

Notoatmodjo, Soekidjo.,2010.

Metodologi Penelitian Kesehatan, PT Rineka Cipta, cetakan Pertama,Jakarta. .,2011.

Kesehatan Masyarakat Ilmu dan Seni, PT Rineka Cipta, cetakan Pertama,Jakarta.

Nuranna, Laila., 2010. Pedoman Tatalaksana Kanker,Fakultas Kedokteran Universitas Indonesia, Jakarta.

Ramli, H. Muchlis., Umbas, Rainy.,Panigoro, Sonar S., 2005. Deteksi Dini Kanker, Fakultas Kedokteran Universitas Indonesia,Jakarta.

Rasjidi, Imam.,2008. Manual Prakanker Serviks, CV Agung Seto, Cetakan Pertama, Jakarta. 2010. 100 Question Answers Kanker pada Wanita, PT Elex Media Komputindo,Jakarta 
Romauli, S., Vindari, Anna, Vida.,2009. Kesehatan Reproduksi, Nuha Medika, Cetakan Pertama,Yogyakarta

Salam, Baharuddin.,2008. Pengantar

Filsafat, Bumi Aksara,Cetakan

Ketujuh,Jakarta. 